its draft budget for 2010, unveiled in September, proposed a cut of $45 \%$ for directly funded basic research. An outcry from the research community reduced that cut to $15 \%$, and an extra $2.8 \%$ top-up for the science ministry is likely to emerge during parliamentary discussions. But this would still be a heavy blow to the country's research base.

Meanwhile, the government has yet to produce its much-heralded law for science. This was supposed to create an independent granting agency and reform the country's inflexible system of academic recruitment, under which university professors and government scientists are civil servants with an automatic right to employment until they retire. Dates for the law to be presented to parliament have been set and then withdrawn, apparently because some parts of the government do not want to exclude scientists from rules that apply to other government employees. Hiring new researchers continues to be a difficult and slow process, and it is almost impossible to offer a competitive package of salary and research money. The science ministry now says that the reform law will be presented to parliament before the end of the year, but the research community is losing faith that this will happen.

In the long-term, industry will be poorly served by a failure to develop and maintain a strong basic-research base. Spain is ill-advised to wed itself to the simplistic and outdated notion that a country can live on transferring knowledge while running down the knowledge generator. This is not a wise way to respond to the financial crisis.

Spain would do far better to emulate the commitments made last month by two other European nations as they too wrestle with the economic downturn. In Germany, a rich country with a near-stagnant economy, the centre-right government is cutting back public expenditure for 2010 everywhere except research and education, to which it is giving huge increases (see Nature 462, 24; 2009). In Greece, a poor country with an economy in recession, the centre-left government says it will likewise cut public expenditure for 2010 everywhere except research and education, to which it is giving modest increases. The governments in both countries also plan to remove some of the red tape that restricts research.

Spain enjoyed one great period of intellectual brilliance in the early nineteenth century, referred to as its Silver Age. Until recently, Spanish scientists were optimistic that they were on their way to a second Silver Age. Now they joke that Spain is heading towards a Bronze Age. But they're not laughing.

\section{A healthy get together}

\section{The recently launched World Health Summit offers a rare chance for dialogue.}

I/ edicine is a social science," wrote the German pathologist Rudolf Virchow in 1848, "and politics is nothing more than medicine on a large scale."

That declaration by Virchow, a social activist and champion of scientific medicine who thought that medicine needed to "enter the political and social life" to fulfil its "great task", has lost little of its relevance today. Many of the problems of medicine are indeed social, and are often best addressed politically on a national or even global scale. Even as ageing populations are spending their last decades in need of medical care, expectations of medicine are rising with the promise of therapies based on genomic information or on stem cells, for example, that could be cripplingly expensive for health-care systems.

So it is, perhaps, fitting that the first World Health Summit, which was designed to address this divergence of the possible and the affordable in health care, took place on 15-18 October at the Charité in Berlin, the hospital where Virchow did his most important work.

The World Health Summit, which is planned as an annual event, grew out of the disappointment felt at the Charite when the G8 economic summit met in Germany in 2007 and - aside from a commitment to fight AIDS in Africa - failed to make health a priority on its agenda. Former Charité president Detlev Ganten teamed up with Axel Kahn, president of Paris Descartes University, and together they organized the M8 Alliance. It is a consortium of major medical institutions from eight leading countries that has taken responsibility for organizing this year's summit and all those that will follow.

The intent of the first health summit was not to produce specific decisions, but to provide a forum for dialogue and consensusbuilding among the world's many players in health - the full range of stakeholders who rarely have the opportunity to gather at the same time. Participants ranged from the researchers who develop hightech therapies, to the politicians and funding agencies who support those developments, to the industries that will commercialize them, the physicians who will apply them and the health-care providers who will have to decide whether to pay for them.

In one session, for example, researchers working on regenerative medicine in the public and private sectors presented their latest thoughts on how to deliver stem cells into the body. And then they dashed eagerly into the next session where health-care providers presented their latest thoughts on reimbursing the cost of therapies based on regenerative medicine.

Such wide-ranging interchanges have been all too rare in the health arena, even as it becomes more important for medical researchers and health-care providers - and all stakeholders in between - to understand each others' potential and constraints. Health needs to be treated in the same comprehensive fashion that nations treat globalization, trade and finance. The first World Health Summit did not attract wide media attention. But over the years, it could and should develop some of the same political clout and visibility accorded to the G8.

The first summit also took place just weeks before the twentieth anniversary of the fall of the Berlin Wall, adding further historical resonance to the occasion. The Charité ended up in East Berlin after the Second World War. Although it had been a privileged research centre under the communist regime, the disappearance of the wall revealed the centre's infrastructure to be crumbling and its science outdated. It is testament to the success and confidence of reunited Germany that the Charité is now ranked as one of the top medical universities in the country, and is able to showcase such an important global initiative on its campus. That initiative is exactly the sort that Virchow would have championed, had he lived today. 